\title{
MACHINE-READABLE TRAVEL DOCUMENTS IN AVIATION SECURITY AND INFORMATION PRIVACY: AN ISLAMIC LAW PERSPECTIVE
}

\author{
Ismail Adua Mustapha*
}

\begin{abstract}
For the purpose of preventing civil aviation offences and maintaining security of civil aviation, passengers are required to give biometric information to be stored in the International Civil Aviation Organization's (ICAO) approved Machine Readable Travel Documents (MTRDs). Such information obtained should be adequately secured against skimming and eavesdropping. Since its inception, many countries including the Muslim countries have adopted the machine to process information of passengers on arrival and departure in the states. Literature have been written on the challenges of skimming and eavesdropping as they are related to information privacy versus aviation security in the civil law but the Islamic law position has yet to be explored. The article therefore attempts to explore the Islamic law position on the use of Machine-Readable Travel Documents (MRTDs) and the challenges of aviation security. The article is qualitative in nature and relies on primary and secondary sources of Islamic law. The article finds that Islamic law expressly preserves individual's information privacy and that skimming and eavesdropping are allowed to promote public security and prevention of evil. It further provides punishment for whoever transgresses against information privacy. It concludes that the adoption of MRTDs to obtain information about private affairs of passengers is in line with the principle of Islamic law.
\end{abstract}

Keywords: Maqasid Shariah, Islamic Law, Skimming,

Eavesdropping, Machine Readable Travel Documents, Aviation security

* Senior Lecturer, Bussiness Law Department, Faculty of Law, University of Ilorin, Ilorin, Nigeria. Email: ismadua@yahoo.com.

[Received: 11 November 2019, Accepted: 6 April 2020, Published: 30 June 2020] 


\title{
PENGGUNAAN MESIN IMBAS DOKUMEN PERJALANAN DALAM BIDANG KESELAMATAN PENERBANGAN: PERSPEKTIF UNDANG-UNDANG ISLAM
}

\begin{abstract}
ABSTRAK
Bagi mengekang kesalahan - kesalahan penerbangan awam dan mengekalkan keselamatan penerbangan awam, penumpang penumpang harus memberi informasi biometrik untuk disimpan dalam Organisasi Antarabangsa Penerbangan Awam (ICAO) melalui Mesin Imbas Dokumen Perjalanan (MRTDs). Maklumat yang diperolehi haruslah dijamin keselamatannya terhadap pemangkasan dan curi dengar. Semenjak diperkenalkan, banyak negara termasuklah negaranegara Islam menggunakan mesin tersebut untuk memproses maklumat penumpang yang memasuki dan keluar dari negara. Penulisan akademik yang ditulis berkenaan cabaran-cabaran pemangkasan dan curi dengar kerana ianya berkaitan dengan maklumat privasi terhadap keselamatan penerbangan di dalam undang-undang konvensional namun ianya tidak dikaji dari sudut undang-undang Islam. Oleh yang demikian, artikel ini mencuba untuk menyelidik penggunaan MRTDs dari sudut undang-undang Islam dan cabaran-cabaran yang dihadapi dalam keselamatan penerbangan. Artikel ini bersifat kualitatif dan bergantung kepada sumber utama dan sumber sekunder undangundang Islam. Artikel ini mendapati bahawa undang-undang Islam dengan jelas melindungi privasi maklumat dan pemangkasan dan curi curi dengar adalah dibenarkan untuk membantu keselamatan awam dan pencegahan kejahatan. Seterusnya, ianya memberikan hukuman kepada sesiapa yang melanggar privasi maklumat. Kesimpulannya, penggunaan MRTDs untuk memperoleh maklumat menngenai urusan peribadi penumpang adalah sejajar dengan prinsip-prinsip undangundang Islam.
\end{abstract}

Kata Kunci: Maqasid Shariah, Undang-undang Islam, Pemangkasan, Curi dengar, Mesin Imbas Dokumen Perjalanan, Keselamatan Penerbangan 


\section{INTRODUCTION}

The primary function of the International Civil Aviation Organization (ICAO) ${ }^{1}$ is to prevent civil aviation from unlawful interference in whatever form. ${ }^{2}$ In furtherance of this function, international conferences and seminars were organized where new innovation and ideas were adopted to improve aviation security in all ramifications. At one of such conferences, the idea of Machine-Readable Travel Documents (MRTDs) was adopted to obtain passengers' information on arrival and departure by air. ${ }^{3}$

The idea of MRTDs started in 1968 and it was well received and adopted by the contracting states ${ }^{4}$ in 1980 beginning with Data page of passenger's passport with "Optical Character Recognition" (OCR) known as Machine Readable Zone (MRZ). This data comprises full details of the holder such as name, date of birth, sex, identification number and expiry date. ${ }^{5}$ The intent and purpose of MRTDs is to

1 The International Civil Organization is a United Nations organization created under article 43 of the Convention On International Civil Aviation ,1944 to be in charge of Civil aviation and responsible for the safety and security of passengers and aircraft. See Chicago Convention on International Civil Aviation 1944 adopted on 7 December 1944 and entered into force on 4 April 1947, ICAO Doc. 7300/9, Ninth Edition, 2006.

2 Huang J, "Aviation Safety, ICAO and Obligation Erga Omnes", Chinese Journal of International Law, 8: 1 (2009):63; See also Abeyratne R. "Aviation Security Law", (Germany: Springer Berlin Heidelberg, 2010): 267. Malaysia ratified and adhered to it on 7 April 1958. See < http://www.icao.int/secretariat/legal/Listof parties/chicago_EN.pdf >. While Nigeria ratified and adhered to it on 14 November 1960 . See < http://www.icao.int/secretariat/legal/Listof parties/chicago_EN.pdf > .

3 Jean Monnerat, Serge Vaudenay, and Martin Vuagnoux, "About Machine-Readable Travel Documents: Privacy Enhancement Using (Weakly) Non-Transferable Data Authentication", J. Phys.: Conf. Ser. 77 012006, (2007): 2.

4 Through the ICAO Doc 9303 which specifies acceptable standard for MRTDs.

5 See Gauruv S.K and Paul A.K Preventing Attacks on Machine Readable Travel Documents (MRTDs) https://eprint.iacr.org/2005/404/pdf, p.4. See also Monnerat J, Vaudenay S and Vuagnoux M, About Machine Readable Travel Documents: Privacy Enhancement Using (Weekly) Non-Transferable Data Authentication" J. Phys.: Conf. Ser. 77 012006,(2007): 2; Riha Z, An Overview of Electronic Passport Security 
collect information about the holder of the document so as to guide against document forgery. ${ }^{6}$ However, challenges of skimming and eavesdropping became the major concern in the use of MRTDs. ${ }^{7}$

The idea of protection of information privacy is well evident in the primary sources of Islamic Law i.e., the Quran and Hadith of the Prophet Muhammad Peace Be Upon Him (PBUH). This is because the Holy Quran says: "Nothing have We omitted from the Book". What therefore left for the Muslim Ummah is to engage in the exercise of a valid Ijtihad ${ }^{9}$ to expand and apply the knowledge of Islamic law to modern day technology such as in the field of civil aviation security. It is on this note that this paper examines the Islamic law position on the use of MRTDs in the realm of aviation security. Thus, the paper is divided into six sections. Section one introduces the topic to the readers. Section two examines the concept of information privacy in civil aviation security under Islamic law.

Features,https://www.researchgate.net/.../226031696_An_Overview_of_ Electronic_Passport_Sec.Sep14, 2016

- Zdenek Riha at Masaryk University, p.2; Tejendra Thapaliya H.K, Biometric Passport: Security And Privacy Aspects of Machine Readable Travel Documents (Being a Final Report, Swiss Joint Master of Science Computer, 2009): 5.

6 Mikko Lehtonen, Thorsten Staake, Florian Michahelles, Elgar Fleisch, Combining RFID and Optical Memory Devices, Auto-ID Labs White Paper WP-HARDWARE-034

7 Juels, A., Molnar, D., and Wagner, D. Security and Privacy Issues in Epassports. In Conference on Security and Privacy for Emerging Areas in Communication Networks - SecureComm (to appear), Athens, Greece, September 2005. IEEE. See also Mary K. McMunn, Machine Readable Travel Documents with biometric enhancement: the ICAO standard International Civil Aviation Organization, WCO Biometrics Conference, 8-9 (December 2005): 21. See also Mikko Lehtonen, Thorsten Staake, Florian Michahelles, Elgar Fleisch, Combining RFID and Optical Memory Devices, Auto-ID Labs White Paper WP-HARDWARE-034, p.4.

8 Q 6:38 (Abdullah Yusuf 'Ali Translation, Islamic Book Trust, Kuala Lumpur, 2007).

9 Ijtihad has been defined as " a process in which one exerts one's efforts to one's full capacity in order to acquire exact or probable knowledge or reach judgment in a given case" See Shahzad Pakeeza \& Fariha Fatima, Ijtihad as a legislative function: Role of Ijtihad, Ifta and Taqleed in Legislative Process, Journal of Islamic Studies, vol. 1 (2016):1. 
Section three discusses the legality of MRTDs under the Islamic law using the principle of Maqasid Shariah. Section four assesses the position of Islamic law on skimming and eavesdropping as challenges to the use of MRTDs. While section five deals with the divine punishment for the skimmer(s) and eavesdropper(s) of information privacy, section six presents concluding part of the paper.

\section{RIGHT TO INFORMATION PRIVACY AND AVIATION SECURITY UNDER THE ISLAMIC LAW}

It has been agreed that privacy is a very difficult term to define ${ }^{10}$ as scholars describe it according to individual perception. That is why Solovo in his article concedes to different descriptions being accorded to the term, where it has been described as a "chameleon-like word", a term suffering from an "embarrassment of meanings", a "powerful rhetorical battle cry". ${ }^{11} \mathrm{He}$ goes further that "privacy is a concept in disarray, it is about everything and hence it seems to be about nothing". ${ }^{12}$ It is submitted that what Solovo was trying to say is that while everybody is demanding for privacy, its nature and scope is yet unknown, hence nobody seems to have understood its precise meaning.

However, Warren and Branders defined the term in 1890 as "right to be let alone". ${ }^{13}$ It has been legally defined as "the right of the

${ }^{10}$ Michael Foutouchos, "The Eauropean Workplace: The Right to Privacy and Data Protection”, Accounting Business and Public Interest, vol. 4(1), (2005): 36. See also Velu,J, "European Convention on Human Rights and the Rights for Private life, the Home and Communication, in A.H Robertson(ed), privacy and human right,(Manchester: MUP,1973): 2731; See also D. Banisar, The Right to Information: Balancing Rights and Managing Conflicts, (The world Bank Institute Working Paper Series, 2011),:6 ; See also D. Calcutt QC, Report of the committee on privacy and related matters, (London: Commd. 1102, HMSO, 1990): 7; See also See per La Forest .J. in R v Broadcasting, standards commission exparte BBC (2003), 3 WLR 1327, 1332; See also $<$ http://gilc.org/privacy/survey/nfro.html>.

11 See D. Solove, "A Taxonomy of Privacy", University of Pennysylvania Law Journal, Vol. 154 (3), (2006):477.

12 Ibid.

13 See Warren and Branders L.D, "The Right to Privacy", HARV. LAW REV., Vol. 4 (1890): 193. 
individual to be protected against intrusion into his personal life or affairs, or those of his family, by direct physical means or by publication of information". ${ }^{14}$ It is submitted that these traditional definitions of privacy only confine themselves to physical intrusion of an aggrieved person; it is now possible in this $21^{\text {st }}$ century to invade into privacy of other "without physically intruding on their space", ${ }^{15}$ this is where the issue of information privacy invasion through electronic machines (internet) comes into play.

According to Marda and Acharya, information privacy refers to the protection of sensitive personal information, specific communications and private conversation. Interception of messages, spying, hacking or tapping phone lines are all activities that impinge on privacy of information. ${ }^{16}$

It is submitted that in aviation security parlance, information privacy can be defined as the protection of passenger's sensitive personal information or communication recorded or obtained by the Aviation Security Provider (screening officer) through the use of MRTDs including biometric passports and visas, and in some states, National security cards ${ }^{17}$ or manually at the screening point of entry and departure in an airport of a particular state. To achieve the maximum security of the passenger's information, the ICAO has approved the use of MRTDs ${ }^{18}$ to store the specific biometric information of the holder in addition to some personal information on the document. Only the passenger has the right to the use and control of his personal information so collected. In addition, each passenger is entitled to determine the circumstance in which the information

14 See David Calcutt, QC in the Report of the Committee on Privacy and Related Matters in 1990 (Commd.5012).

15 See V. Marda and B. Acharya, "Identifying Aspects of Privacy in Islamic Law", The Internet Centre for and Society $<$ http: cis-india.org/internetgovernance/blog/identifying-aspects-of-privacy-in-islamic-law.

16 Ibid.

17 See Conte A, Human Rights on the prevention and punishment of terrorism, (Germany: Springer Verlag Berlin, Heidelberg, 2010): 655.

18 ICAO, Machine Readable Travel Documents, Annex 9, Chapter 5, paragraphs 3- 47, ICAO Doc. 9303; See also Conte A, Human Rights on the prevention and punishment of terrorism, (Germany: Springer Verlag Berlin, Heidelberg, 2010): 655. 
about him will be published, or accessible to the public. ${ }^{19}$ That was why the ICAO warned that information stored in these machines should be secured against "skimming" or "eavesdropping" so that the passenger's data would not be read from the vicinity of the airport. ${ }^{20}$ The challenges of skimming and eavesdropping in the MRTDs raises privacy issue in the collection of passenger's data information.

In Islamic Jurisprudence, privacy is not defined but described within the primary sources of Islamic law, which is dealt with later. Historically, in the pre-Islamic era the notion of right to privacy was not recognized as any member of the community was free to enter each other's house without permission sought and obtained. The slogan during this era was just to say 'good morning' or 'good evening'. This unscheduled visit and entry sometimes invaded the "privacy of the people and their women folk". ${ }^{21}$ The invasion into the privacy of individuals has to change right from the beginning of the Islamic era. In this respect, everybody including non-Muslims has the right to privacy and no one is allowed to enter another person's house without permission being sought and granted. This assertion is evident in both the Quran and Hadith of the Prophet.

Allah (S.W.A) commands the Muslims in Quran 24 verse 27 thus:

O Believers do not enter other houses than your own until you have the approval of the inmates and have wished them peace; this is the best way for you: it is expected that you will observe it. ${ }^{22}$

First hand implementation of this verse was practiced by the Prophet Muhammad, Peace Be Upon Him (PBUH) himself. It was reported that:

The Prophet went to the house of Sa'd bin 'Ubadah and sought for the permission of inmates twice after saying: Assalam alaykun wa Rahmatullah (peace be upon you and mercy of Allah), but nobody

${ }^{19}$ Golumbic, M.C, The Balance between security and civil rights, in fighting terror, (Germany: Springer Berlin, 2008):38.

${ }^{20}$ ICAO, Guideline on Machine Readable Travel Documents and passengers and facilitation, $17^{\text {th }}$ April 2008, 18.

21 The Right to Privacy in Islam, in Human Right in Islam, < http://islamicstudies.islammessage.com/Content_Details.aspx?id=3790 $>$.

${ }^{22}$ Quran 24:27. 
responded. He repeated it for the third time when no response was received; he turned his back and left. Sa'd came out and ran after him, and said "O Messenger of Allah, I was hearing you all right but I desired to have Allah's peace and mercy invoked upon me through your sacred tongue as often as possible; therefore, I was replying to you in a low voice. $^{23}$

In another Hadith reported by Huzail bn Shuranbil that:

A man came to see the Prophet Muhammad and sought his permission for entry while standing just in front of the door. The Holy Prophet said to him: "Stand aside: The object of the commandment for seeking permission is to prevent casting of looks inside the house. ${ }^{24}$

Abu Dawud further reported that:

The practice of the Holy Prophet was whenever he went to see somebody; he would stand aside, to the right or the left of the door, and seek permission as it was not then usual to hang curtains on the doors. ${ }^{25}$

To further compliment the above injunctions, it was also reported that the Prophet stated that had he knew a man was peeping into his dwelling house, he would have used an iron comb which he was using to scratch his head to pierce the eye of that man for failure to take permission from him. ${ }^{26}$ This is due to the fact that the man had breached the right to privacy of the inmates.

${ }^{23}$ See Ahmad Hassan, Sunan Abu Dawud: English Translation with Explanation Notes, Vol. III, (New Delhi: Kitab Bhavan, 1990), Hadith No: 5166, at Pp. 1430-31.

${ }^{24}$ See Ahmad Hassan, Sunan Abu Dawud: English Translation with Explanation Notes, Vol. III, (New Delhi: Kitab Bhavan, 1990), Hadith No: 5155, at P. 1428.

25 See Ahmad Hassan, Sunan Abu Dawud: English Translation with Explanation Notes, Vol. III, (New Delhi: Kitab Bhavan, 1990), Hadith No: 5167, at Pp. 1431.

${ }^{26}$ See. Mohammed Mahdi Al'Sharif, Al'Bukhari's Sahih: The correct traditions of Al'Bukhari. Vol. IV (Beiruit- Lebanon: Dar al-kotob AlIlimiyah, 2007) Hadith No: 6241 at p. 144. 
The above injunctions are the clear and unequivocal manifestation of bodily privacy under Shariah. It is inferred from the last Hadith that a person who peeps into the house of another was regarded as a trespasser who needs to be abated. A wider application of these Hadith to humanity is that no matter how close you are to an inmate; it is mandatory to seek permission and where granted before entering a house.

The Presidency of Islamic Research, IFTA, Call and Guidance of Saudi Arabia explain the importance of the above verse when it maintains that: "The Muslim principle of asking permission and exchanging salutations ensures privacy without exclusiveness and friendliness without undue familiarity". ${ }^{27}$

It is submitted that privacy is not restricted to bodily privacy under Islamic Law. The law recognizes what is called as information privacy which may be defined as the right of individuals to be let alone for the enjoyment of secrecy of any personal communication and information relating to his or her private affairs. This is evident from Allah's injunction in Quran 49 verse 12 where Allah commands:

O you who believe! Avoid much suspicion; indeed, some suspicions are sins. And spy not, neither backbite one another. Would one of you like to eat the flesh of his dead brother? You would hate it (so hate backbiting). ${ }^{28}$

The practice of the Prophet Muhammad (PBUH) in relation to the above verse was reported in the Hadith narrated by Abu Hurairah where the Prophet (PBUH):

Beware of suspicion, for suspicion is the worst of false tales; and do not look for other's faults, and do not spying on one another, and do not practice Najs and do not be jealous of one another and do not hate one

${ }^{27}$ See The Holy Quran: English Translation of the meanings and Commentary, Revised and Edited by the Presidency of Islamic Researches, IFTA, CALL AND GUIDANCE, p. 1011.

${ }^{28}$ Quran 49: 12. 
another, and do not desert (stop talking to) one another. And O Allah's worshippers! Be brothers. ${ }^{29}$

In another Hadith, Abdullah ibn Abbas reported the Holy Prophet (PBUH) to have said that: "Whoever glances through the letter of his brother without his permission, glances into fire." ${ }^{30}$ The above verse and the Hadith emphasises that to respect one's privacy is an obligation upon every Muslim and failure to do so is likely to constitute a breach of fundamental right to privacy in Islamic and civil law. In fact, both laws preach the right to privacy as one of the inalienable rights. It is submitted that the right to privacy generally and specifically information privacy is absolute. For example, an Islamic state may source information or glance through the information of an alleged accused person for his arrest without his consent being sought and obtained. This is practically possible in the aviation industry through the use of MRTDs which stores information about a traveller for the purpose of tracing the history of an alleged unruly passenger without his permission being sought and obtained. The justification for this submission is that since the purpose of Shariah is to protect the general public, one of the means to achieve this purpose is the adoption of MRTDs.

\section{NATURE AND LEGALITY OF THE MACHINE-READABLE TRAVEL DOCUMENTs (MRTDs) UNDER ISLAMIC LAW}

MRTD is an electronic machine which is adopted to receive and store biometric information of passengers for the purposes of identifying the authenticity of the information as well as the giver. The adoption of MRTDs, even though with certain reservation, has received accolades from aviation security providers across the world. The germane question now is "what is the legality of its adoption in the eyes of Shariah - Islamic law?

29 See Muhammad Mushin Khan, The Translation of the Meanings of Sahih Al-Bukhari: Arabic-English, Vol. 2 (Riyadh: Dar-us-Salam, 1997) Hadith No; 1521 , at p. 346.

${ }^{30}$ Ahmad Hassan, Sunan Abu Dawud: English Translation with Explanation Notes, Vol. III, (New Delhi: Kitab Bhavan, 1990), Hadith No: 1480, at Pp. 388-89. 
Maqasid al-Shariah (plural of Maqsada) was interpreted to mean purpose, intent, end, goal, principle and objective. ${ }^{31}$ It has been defined as the fundamental objectives or goals of the Islamic law. According to Muhammed Adil, Maqasid Shariah is the realization of benefit to the people, concerning their affairs both in this world and the hereafter. According to him, the aim of Shariah is to secure benefits for the people or protect them against corruption and evil. ${ }^{32}$ It is submitted that one of the evils sought to be protected is unlawful interference with civil aviation the consequences of which could result to death of human being, loss of property, psychological imbalance and distortion of states relation. The Quran explained the main objectives of Shariah when it declares: "And We have sent you (O Muhammad (PBUH)) not but as a mercy for the 'Alamin (mankind, jinns and all that exists)". ${ }^{33}$

Accordingly, Ibn Qayyim al-Jawziyyah while explaining the above verse maintains that the aim of Shariah is to safeguard the people's interests and prevent them from harm in this world and the hereafter. He further explains that if the injunctions of Quran are not aimed at benefitting mankind, then there would be little value to the Quran as a revelation and guide". ${ }^{34}$

In the light of the above meaning of the term, it can therefore be defined as the purpose, intent, goal, objective and principles of Islamic law upon which all aspect of human existence is based.

31 Mohammad al-Tahir Ibn Ashur, Ibn Ashur-Treatise on Maqasid AlShariah, trans. Mohamed El- Tahir El-Mesawi, vol. $1^{\text {st }}$ (LondonWashington: International Institute of Islamic Thought (HIT), 2006), p. ii. See also: Jasser Auda, Maqasid Al-Shariah, An Introductory Guide, (Herndon, VA: IIIT, 2008) cited in Muhammad Adil Khan Afridi, Maqasid Al-Shariah And Preservation Of Basic Rights Under The Theme "Islam And Its Perspectives On Global \& Local Contemporary Challenges" Vol. 4, Journal of Education and social Sciences (2016) p. 274.

32 Muhammad Adil Khan Afridi, Maqasid Al-Shariah And Preservation Of Basic Rights Under The Theme "Islam And Its Perspectives On Global \& Local Contemporary Challenges" Vol. 4, Journal of Education and social Sciences (2016) p. 278.

33 Quran 21: 107.

${ }^{34}$ Mohammad Kamal Imam, Al-Daleel Al-Irshadilla Maqasid al-Shariah al-Islamiyyah (London: al- Maqasid Research Centre, 2007), Introduction, p.iii. 
Maqasid Shariah is basically classified into three viz; Darruriyah, Hajiyyah and Tahsiniyyah. ${ }^{35}$ Darruriyah has been literally interpreted to mean essentials or necessities. ${ }^{36}$ According to Muhammad Adil Khan Afridi, the essentials are "matters on which the religion and worldly affairs of the people depend upon; their neglect will lead to total disruption and disorder and could lead to an undesirable end. These essentials must be protected and all measures that aim at safeguarding them must be taken, whether by the individual or government authorities". ${ }^{37}$ There are "five fundamental elements of human existence", namely: (1) life, (2) religion, (3) reason, (4) family, and (5) property. ${ }^{38}$

\section{PROTECTION OF LIFE}

${ }^{35}$ See Abdulraheem Taofeeq Abolaji, An Expository Study of Right of children to Health under the Shariah and Nigerian Law (Ph.D Thesis: University Sains Malaysia (USIM): 2016) 66. See also Mohammed Akram Laldin, Islamic Law: An Introduction, (Research Centre IIUM: Malaysia, 2006) 17.

${ }^{36}$ See Abdulraheem Taofeeq Abolaji, Simple Biological Cycle: Explicating Mosasid Shariah As a Tool For Protecting Children's Right To Health, International Journal of Research Without Boundaries ( Le Journal Int'l De Recherche Sans Frontieres) (2016) 172; See also Abdulraheem Taofeeq Abolaji, An Expository Study of Right of children to Health under the Shariah and Nigerian Law (Ph.D Thesis: University Sains Malaysia (USIM): 2016) 66

${ }^{37}$ Muhammad Adil Khan Afridi, Maqasid al-Shariah and Preservation of Basic Rights under the theme "Islam and its perspectives on global \& local contemporary challenges"vol. 4, Journal of Education and Social Sciences, (2016)279.

${ }^{38}$ See al-Shatibi, " Al-muwafaqaht fi Usul al-Ahkam", Vol. II, p.4; Muhammad Tahir Ibn "Ashuri, " Maqasid al-Shar'ah al-Islamiyya", Dar As-Salm; Jasser Auda, " Maqasid al-Shariah as Philosophy of Islamic Law",( London, Washington: The International Institutute of Islamic Thought, 2008) p. 2; See also Abdulhameed Yusuf Badmas, “Al-kulliyat Al-Daruriyyah Between Limitation and Open-endedness: A critical Analytical" (Ph.D Thesis, International Islamic University, Malaysia, 2013) pp. 48-49 and 87; Al-Ghazali, "Mustasfa", Vol. 1, pp.216-217; Nyazee, "Theories of Islamic Law", p.213. See also Mohammed Akram Laldin, Islamic Law: An Introduction, (Research Centre IIUM: Malaysia, 2006) 18. 
Life of human being is sacred and sought to be protected in an Islamic state. It is mentioned in the Quran that no one may simply kill any life without any valid reason as laid down in the following verses:

And do not kill anyone who Allah has forbidden, except for a just cause. And whoever is killed (intentionally with hostility and oppression and not by mistake), we have given his heir the authority (to demand Qisas, Law Equality in punishment or to forgive, or to take diya (blood money) But not let him not exceed the limits in the matter of taking life (i.e. he should not kill anyone except the killer only). Verily, he is helped by Islamic law. ${ }^{39}$

Further in another verse Allah says the killing of one life without justification is entirely unacceptable in the eye of Allah (swt):

Thus, we decreed upon the children of Israel that whoever kills a soul unless as legal punishment for murder or for corruption in the land, it is as if he had slain mankind entirely. And whoever saves one soul, it is as if he had saved mankind entirely. ${ }^{40}$

The Prophet was reported to say:

...Verily, Allah the Exalted has made sacred your lives, your wealth, and your honour except by right justice, just as your day, your city, and your months are sacred... ${ }^{41}$

In another Hadith narrated by Anas Bn Malik, the Prophet was reported to have said:

The biggest of Kaba'ir (greatest sins) are: (1) to join others as partners in worshipping with Allah, (2) to murder a human being, (3) to be undutiful to ones parents, and (4) to make a false statement, or said, " to give a false witness. ${ }^{42}$

${ }^{39}$ Quran 17:33.

${ }^{40}$ Quran 5:32.

${ }^{41}$ See Mohammed Mahdi Al'Sharif, Al'Bukhari's Sahih: The correct traditions of Al'Bukhari. Vol. I (Beiruit- Lebanon: Dar al-kotob AlIlimiyah, 2007) Hadith No: 1739at p. 423.

42 See Mohammed Mahdi Al'Sharif, Al'Bukhari's Sahih: The correct traditions of Al'Bukhari. Vol. IV (Beiruit- Lebanon: Dar al-kotob Al- 
According to Ibn Kathir, life of human being, Muslim or NonMuslim can only be taken as a means of self-defence in a war, as a legal punishment to serve as deterrence to person(s) who may have criminal intent and to those who commit corruption on the land. ${ }^{43}$

From the above authorities, it was found that what Allah frowned at is killing without justification, which is murder. In fact, there is no distinction between Muslim and non-Muslim lives when it comes to protection of lives. This is borne out of the fact that Allah has dignified the entire life of human being as a whole. This is clearly evident in the Holy Quran where Allah states:

We have certainly dignified the children of Adam and carried them on the land and sea and provided for them on of the good things and preferred them over much of what We have created with definite preference. ${ }^{44}$

It is therefore the responsibility of state authority to do all it can to protect the lives of its citizens in all ramifications. That is why Allah has ordained punishment for killing to include killing of the culprit, payment of blood homage ${ }^{45}$ and in the hereafter, the reward is hell fire. ${ }^{46}$

It is submitted that the protection of civil aviation connotes securing the lives which Allah has made sacred. These includes lives of passengers, pilots and aviation workers in general () against being taken without just cause. ICAO and the various state civil aviation authorities across the world are duty bound to device means of protecting the lives of passengers, pilots as well as aviation workers. One of these means is the adoption of MTRDs wherein it is used to collect information about a particular passenger who may later turned to be a civil aviation criminal(s) having the intention to commit any of the aviation offences particularly aircraft hijacking and aircraft

Ilimiyah, 2007) Hadith No: 6871at p. 297; and Hadith No; 6870 at p. 296.

${ }^{43}$ See Tafseer Ibn Kathir, Quran 5:32.

${ }^{44}$ Quran 17:70.

${ }^{45}$ Quran 17:33

${ }^{46}$ Quran 4: 93. 
sabotage among other crimes. The application of this process will definitely, if properly administered, identify such an offender who may want to sabotage the aircraft.

\section{PROTECTION OF PROPERTY}

While it is admitted that passengers' lives must be protected against unlawful killing in all ramifications, the same goes to the protection of their properties against destruction. In this respect Allah, the Most Merciful orders the entire human being thus:

The punishment for those who wage war against Allah and His Messenger (in respect of endangering the security of the state established under the Divine Law) and strive with might and main for mischief through the land. ${ }^{47}$

According to Ibn Abbas, the above verse was revealed to the Prophet Muhammad (PBUH) on the activity of the people of Hilal Ibn 'Uwaymir who terrorized, and killed a group of people from Banu Kinanah when the group was travelling to Madinah to declare and accept Islam. In fact, their belongings (wealth or properties) were unlawfully seized as booties. ${ }^{48}$

From the above verse, the clauses "wage war against Allah, and mischief through the land" are symbiotic in nature. While "waging war against Allah" can be interpreted to include absolute disobedience to Allah's command, the word 'mischief' has been interpreted to include all acts that have been prohibited in the sight of Allah. These include oppressing people, killing of people unjustly, making life difficult for people, public harassment, and corruption. ${ }^{49}$ It is further submitted that unlawful seizure or destruction of another person's property without lawful justification is an act of mischief in

47 Quran 5: 33-34.

48 See Abdullah Ibn Abbas, Tanwir al-Miqbas min Tafsir Ibn Abbas, Translated by Mokrane Guezzou, (Jordan: Royal Aal al Bayt Institute for Islamic Thought, 2007), 168.

49 See Quran 7:103, Quran 28: 4. See also Ibn Kathir, Stories of the Prophets, Darul Ishaat, 2009),p. 187.See also Maulana Mohammad Taqi Usmani, Ma'ariful Quran, Vol.6., p.633; Ajmeri, F., Dawat-Ul Quran, Vol. 2, p.1323; Sayyid Qutb, In the Shade of Quran ( The Islamic Foundation, Vol. 6.), p. 163. 
the sight of Allah. In this respect, Prophet Muhammad (PBUH) was reported to have said:

...Verily, Allah the Exalted has made sacred your lives, your wealth, and your honor except by right justice, just as your day, your city, and your months are sacred.... ${ }^{50}$

Also, in another verse, Allah says:

And eat up not one another's property unjustly (in any illegal way e.g. stealing, robbing, deceiving, etc.), nor give bribery to the rulers (judges before presenting your cases) that you may knowingly eat up a part of the property of others sinfully. ${ }^{51}$

There are several ways of eating up another's property unlawfully. These include but not limited to unlawful seizure and destruction of aircraft. It is therefore the responsibility of state authorities to protect and guard against any mischievous act in relation to community or individual property. One of the ways to perform this sacred responsibility is through the adoption of MRTDs.

The MRTDs is adopted to secure and protect the aircraft and passengers' properties against unlawful seizure and destruction while the aircraft is in service and when the passenger accompany their baggage or loaded on board the aircraft. Such properties include both hand and checked baggage. In this article, a hand baggage refers to property that is allowed to accompany the passenger into the aircraft, otherwise known as accompanied luggage, while a checked baggage or unaccompanied luggage is a property that will undergo separate security screening before being loaded into the aircraft baggage compartment.

In order to protect passengers, a holistic approach to proper identification of air traveller through the use of MRTDs may lead to detection of forged document. It is submitted that a person who is found to possess forged travelling document has committed a crime.

${ }^{50}$ See Mohammed Mahdi Al'Sharif, Al'Bukhari's Sahih: The correct traditions of Al'Bukhari. Vol. I (Beiruit- Lebanon: Dar al-kotob AlIlimiyah, 2007) Hadith No: 1739at p. 423.

${ }^{51}$ Quran 2:188. 
Thus, such a criminal may have the intention to either hijack or sabotage the aircraft leading to absolute destruction of passengers' properties as well as the aircraft. The destruction in this respect amounts to unlawful destruction which Allah obliged human race to abstain from. Therefore, the importance of MRTDs in the protection and security of passengers' and airlines properties is in consonance with the principle of Maqasid Shariah.

\section{INTELLECT}

Allah has endowed human being with $A q l$ or intellect (mind). This is the mechanism upon which men are able to differentiate between what is good and bad. It is also an avenue to distinguish men from animals. The intellect is an important drive towards a successful living in this world and good reward in the hereafter. It is necessary for human being to make use of the intellect bestowed on him as means to abstain from evil and do good which is the essence of Maqasid Shariah as Allah says in one of the Quranic Verse;

He grants Hikmah to whom He wills, and he, to whom hikmah is granted, is indeed granted abundant good. But none remember (will receive admonition) except men of understanding. ${ }^{52}$

According to Crow, aql or intellect is an innate trait of native human constitution. ${ }^{53} \mathrm{He}$ further explained intellect as the locus for comprehension and understanding of speech which comprise of divine address to human mediated scriptural revelation. On the role of intellect, the author asserts that without $a q l$ human intelligence cannot be given a providential role by the Creator.

The intellect and sanity of passenger, pilots, and crew and aviation workers is sought to be preserved due to its importance in achieving utmost purpose of worshipping the Creator. Preservation of intellect/sanity is achieved through the use of machines to screen passengers within at point of entry and exit so that stakeholders can

52 Quran 2: 269.

53 Crow, Karim Douglas. "The Intellect Islamic Thought: Mind and Heart." KATHA-The Official Journal of the Centre for Civilisational Dialogue 2, no. 1 (2018): 1-22. 
enjoy peace of mind and mental well-being knowing that passengers and aviation workers citizens are safe.

This clearly showed the importance of intellectuals in development of human race in this world. Therefore, it needs be protected by whatever means. That is why the adoption of MRTDs as a measure to obtain information on passengers is highly encouraged, however subject to the protection against skimming and eavesdropping. It is submitted that it is through the application of intellect that human beings are able to invent some valuable equipment that make it easy to worship Allah. Such things include but not limited to aircraft that airlifts pilgrims to Mecca; and other security equipment including but not limited to MRTDs at all airports. All these machines are one way or the other relevant to the protection of human intellect in that they are necessary to guard against unlawful seizure of aircraft and destruction of passengers' baggage to mention but a few which are the agents of intellect destruction.

It is important to mention that the human intellect must be protected and secured against psychological disorder that may occur in the event of aircraft hijacking or aircraft sabotage or hostage-taking of passengers. It is on this note that the issue of MRTDs comes into use for the purpose of receiving information about would-be aviation criminals who may intend to hijack the aircraft leading to psychological disorder of the passengers on board and their relatives. Therefore, any event that is likely or that will cause mental imbalance resulting from the aviation industry must be protected and one of such means of protection is MRTDs.

\section{RELIGION}

It is the right of an individual to practice his religion without any fear of terrorism. One of the important aspects of the religion which is obligatory on Muslims is to perform hajj as one of the five pillars of Islam. Allah (SWT) states thus:

And proclaim to mankind the Hajj (pilgrimage). They will come to you on foot and on every lean camel, they will come from every deep and distant (wide) mountain highway (to perform hajj). ${ }^{54}$

${ }^{54}$ Quran 22: 27. 
In another verse, Quran states:

Verily, As-Safa and Al-Marwah (two mountains in Makkah) are of the Symbols of Allah. So it is not a sin on him who performs Hajj or 'Umrah (pilgrimage) of the House (the Ka'bah at Makkah) to perform the going (Tawaf) between them (As-Safa and Al-Marwa. And whoever does good voluntarily, then verily, Allah is All-Recogniser, AllKnower. ${ }^{55}$

The above verses raise two important issues. These are right to perform hajj as an act of worship, and means of transportation to Makkah. One of the ways of worshipping Allah is performance of hajj. The consequence of performing hajj has well been stated by the Holy Prophet Muhammad. He said:

Whoever performs hajj to this House (Ka'abah) and does not approach his wife for sexual relations nor commits sin (while performing Hajj), he will come out as sinless as a newly born child (just delivered by his mother).$^{56}$

In another Hadith, the Prophet was reported to have said: "... and the reward for Hajj Mabrur (the one accepted by Allah) is nothing but paradise. " 57

According to the Quran, the primitive modes of transportation as at the time when this verse was revealed to the Holy Prophet (PBUH) during the early days of Islam were foot trekking; and leaning on the camel. At that time, many Muslims travel via any of these modes to the Holy land to perform hajj without fear or worry of any of the unforeseen circumstances that are inimical to their wellbeing or destructive in nature. However, in this modern day, the predominant mode of transportation to the Holy land is air transport which has

55 Quran 2: 158.

56 See Muhammad Mushin Khan, The Translation of the Meanings of Sahih Al-Bukhari: Arabic-English, Vol. 2 (Riyadh: Dar-us-Salam, 1997) Hadith No; 1521, at p. 346.

57 See Muhammad Mushin Khan, The Translation of the Meanings of Sahih Al-Bukhari: Arabic-English, Vol. 2 (Riyadh: Dar-us-Salam, 1997) Hadith No; 1773. 
been described as the fastest and safest of all the modes of transportation.$^{58}$ It has the ability to carry larger proportion of Muslims from their respective states to the Holy land with ease and little hardship unlike in the olden days where the pilgrims would suffer before they could reach their destination. Thus, the contribution of air transport to the act of worshipping is immense.

One of the challenges to the use of air transport is unlawful interference which includes aircraft hijacking and sabotage of aircraft amongst others. Many aircraft had been hijacked or sabotaged due to inadequate security from the aviation security providers; airport authorities and airline operators across the States. ${ }^{59}$ It is these interferences that MRTDs was designed to suppress and prevent.

It is submitted that security and protection of aircraft against any of the unlawful interference amounts to protection and security of religion since one of the modern means of transportation to the holy land is air transport. Thus, the need to adopt MRTDs to scan and receive information for the purpose of identifying and detecting the criminals from the intending righteous Muslim pilgrims to the Holy land is a welcome development under the Shariah.

\section{FAMILY OR LINEAGE}

It is submitted that the adoption and application of MRTDs is one of the means to protect family or lineage. This is achievable considering the aim and objective of the machine in the protection of civil aviation against any of the unlawful interference.

From the onset, "family" in this respect is interpreted to mean generality of human race irrespective of religious, colour, language affinity since human beings are created from the same source. This is

58 See Ismail Adua Mustapha, Adequacy of Implementing Annex 17 to the Chicago Convention on Aircraft security In Nigeria, ANULJ, Vol. 25 (1), (2017), 163.

59 See Ismail Mustapha Adua, "International Law on Aircraft Hijacking: The Practice in Malaysia and Nigeria" (PhD Thesis, International Islamic University Malaysia, 2014), 40-53. See also Ismail Adua Mustapha, "An Overview of the International and Nigerian Legal Framework For Prevention of Aircraft Sabotage", Centre Point Journal (Humanities Edition) 17(2) (2014), 2-4. 
clearly evident in the Holy Quran where Allah says thus: "It is $\mathrm{He}$ who created you from a single person..." It is this elaborate meaning of family that civil aviation is dealing with, thus, the need to protect this family against destruction. This is achievable through the adoption and application of MRTDs designed to collect individual passenger's information in the process of travelling through the air transport. The information so obtained shall be screened for the purpose of detecting would be criminal(s) in the aviation industry. The purpose therefore is to protect the family against destruction on board aircraft.

It is submitted that the totality of the doctrine of Maqasid Shariah is to guide against violence and to live in peace and harmonious relationship. That is why the above principles herein discussed are for the purposes of maintaining peaceful coexistence in aviation industry as preached and emphasized in both the Quran and Hadith of the Prophet Muhammad (PBUH). In this regard, Quranic provisions supporting the fact that Islam and violence are opposite to each other can be seen in Quran 2: 205, Quran 10: 25, and Quran 25: 63 just to mention a few. In the verses of the Holy Quran, Allah categorically enjoins Muslims to embrace peace in all ramifications and shun violence.

The Prophet in his Hadith was reported to have said that a true believer should refrain from harming his neighbour; ${ }^{60}$ enjoining the spread of peace among each other; ${ }^{61}$ and all Muslims should refrain from committing violence of any kind. ${ }^{62}$ It is in the interest of preventing violence activities that the aviation practitioners under the auspices of ICAO designed MRTDs. The action of aviation practitioner is therefore in compliance with the principle of Islamic law on the maintenance of peace and shunning of violence.

60 See Muhammad Mushin Khan, The Translation of the Meanings of Sahih Al-Bukhari: Arabic-English, Vol. 8 (Riyadh: Dar-us-Salam, 1997) Hadith No. 6018 at p. 38.

61 See Imam Muhammad Bin Yazeed Ibn Majah Al-Qazawini, Sunan Ibn Majah: English Translation, Vol. 5 (Riyadh: Darussalam, 2007) Hadith No. 3692, p. 29.

62 See Kabir Helminski (ed.) "A collection of Sound Hadith on Peace and Justice: Compiled from reliable sources by M. Hafiz Syed < https://www.spritualityandpractice.com> assessed on $17^{\text {th }}$ April, 2020. 


\section{CHALLENGES IN THE ADOPTION AND APPLICATION OF MRTDS: ISLAMIC LAW PERSPECTIVE}

The ICAO position on the adoption and application of the MRTDs is that all contracting states should be wary of skimming and eavesdropping on any of the information so obtained from the respective passengers. What then is the Islamic law position on skimming and eavesdropping on the information so obtained from the passengers?

Evidences abound from the primary sources of Islamic law (Quran and Hadith) on the legality or otherwise of the act of skimming or eavesdropping. Quran 49 verse 12 states thus:

O you who believe! Avoid much suspicion; indeed, some suspicions are sins. And spy not, neither backbite one another. Would one of you like to eat the flesh of his dead brother? You will hate it (so hate backbiting).

It is submitted that a cursory look at the above verse revealed that the word "Skimming" is not directly mentioned. However, the Arabic term for the bold word in the above quoted verse of the Quran is Tajassus which Allah has prohibited. The act of spying includes "reading other people's letters, listening secretly to private conversation, peeping into the neighbour's house, and trying to get information in different ways about domestic life or private affairs of others". ${ }^{63}$ Skim is "to read quickly in order to find a particular point or the main point". ${ }^{64}$ Therefore the act of reading other people's information or letter quickly to get different information about the domestic or private life of others could be referred to as "skimming". It is safely concluded that the word spying and skimming are synonymous and could be used interchangeably.

The Islamic law prohibition on Thasos was demonstrated in the Hadith of the Prophet Muhammad, narrated in Al-Bukhara and Muslim from Abu Hurrah that the Prophet said:

63 Surah Al-Hujurat 49:11-18: Towards Understanding the Quran with kind permission; Islamic Foundation UK www.islamicstudies.info assessed on $20^{\text {th }}$ June, 2019.

64 See Oxford Advanced Learner's Dictionary, $8^{\text {th }}$ edition, (International Student's Edition), Oxford University press, p. 1392. 
Beware of suspicion, for suspicion is the fastest of speech. Do not eavesdrop; do not spy on another; do not envy another; do not for sake one another; do not hate one another. Be, O slave of Allah, brother. ${ }^{65}$

The word 'eavesdropping' interpreted to mean "the act of secretly listening to the private conversation of others without their consent" ${ }^{66}$ This interpretation is the same with an interpretation of the term given by Al-Away when he said Thasos (eavesdropping) is "to listening "(sic) to people when they are talking without their permission, or eavesdropping at their doors" while Tajassus (skimming) is "to search for something". 67

It is submitted that what Islamic law dislikes about skimming is the illegal act of searching for information about person's privacy through reading or copying document or through electronic device in order to use it without the owner's consent being sought and granted, while eavesdropping is prohibited on the ground of not being reading or copying but on secretly listening to private conversation of people without their consent. It can safely be concluded that both skimming and eavesdropping contradict basic human right to private information.

\section{PUNISHMENT FOR SKIMMING AND EAVESDROPPING UNDER THE ISLAMIC LAW}

In the light of Islamic law, punishment for the acts of skimming and eavesdropping is not stated in the Holy Quran but in the Hadith of the Prophet Muhammad. What is contained in Quran chapter 49 verse 12 is a serious prohibition of the acts mentioned therein. It is therefore imperative to consider the Hadith of the Prophet Muhammad with regards to punishment. Accordingly, Al-Bukhari narrated from Ibn Abass that the Prophet Muhammad is reported to have said:

${ }^{65}$ See Muhammad Mushin Khan, The Translation of the Meanings of Sahih Al-Bukhari: Arabic-English, Vol. 8 (Riyadh: Dar-us-Salam, 1997) Hadith No: 6066, at p. 61.

${ }^{66}$ See Bryan A.G, Black's Law Dictionary, $8^{\text {th }}$ Edition, p.551.

${ }^{67}$ See Tafsir Ibn Kathir, Vol.9 (Abridged) (Riyadh: Darulssalam, 2003), 202. See Oxford Advanced Learner's Dictionary of Current English, $7^{\text {th }}$ Edition, Oxford Unipress, p. 1378. 
Whoever listens in on other people's conversation when they do not like that will have molten lead poured into his ears on the Day of Resurrection... ${ }^{68}$

It is submitted that from the above Hadith, there is no worldly punishment for both eavesdropping and skimming under the Islamic law but that in the hereafter which is greater in all ramifications. It is therefore incumbent on the Islamic states to legislate on the worldly punishment for the crime of eavesdropping and skimming, bearing in mind certain exception(s) to the crimes.

\section{EXCEPTIONS TO THE OFFENCE OF SKIMMING AND EAVESDROPPING}

Without fear of contradiction to the principle of Islamic law, skimming and eavesdropping are allowed in certain circumstance which includes skimming and eavesdropping in furtherance of promotion of good and prevention of evil (corruption on the land).

While it is so glaring that Islamic law prohibits investigation into people's private affairs, it allows Islamic government to survey individual behaviour for the removal of corruption among other vices in the society. The Holy Quran attested to this when Allah decree in Quran the prohibition of corruption in all ramifications.

The word corruption has been interpreted in Arabic language to mean "Fasad" ${ }^{69}$ It is also synonymous to "mischief" on the land ${ }^{70}$ or

${ }^{68}$ See Muhammad Mushin Khan, The Translation of the Meanings of Sahih Al-Bukhari: Arabic-English, Vol. 9 (Riyadh: Dar-us-Salam, 1997) Hadith No; 7042 at p. 115.

${ }^{69}$ See Hons Wehr, J. Milton Cowan, A Dictionary of Modern Written Arabic, $3^{\text {rd }}$ ed., Spoken Language Service, 1976, p. 712. See also Oliver Leaman, Islamic Philosophy, pp.140-141.

${ }^{70}$ Oliver Leaman, Controversies in contemporary Islam, Routledge, 2013, chapter 9. See also Ibn Kathir, Stories of the Prophets, Darul Ishaat, 2009),p. 187.See also Maulana Mohammad Taqi Usmani, Ma'ariful Quran, Vol.6., p.633; Ajmeri, F., Dawat-Ul Quran, Vol. 2, p.1323; Sayyid Qutb, In the Shade of Quran ( The Islamic Foundation, (Vol. 6.), p. 163. 
"disturbance" of the public peace. ${ }^{71}$ The Islamic classical jurist referred to it as "hirabah". ${ }^{72}$ Accordingly, Maliki School defines hirabah as an "act of terrorizing people for the purpose of robbery or other purposes". ${ }^{73}$ It is therefore submitted that the acts of eavesdropping and skimming are permissible to prevent acts of terrorism in whatever form, be it against civil aviation or any other disturbance(s) of public peace. Since the intention in this case is to prevent evil and promote good in the society.

\section{CONCLUSION}

The right to collect information from respective individuals on any social affairs, for the protection of public safety and security is not contrary to the principle of information privacy under the Islamic law. However, what Islamic law prohibits is collection of individual's private information. It is this kind of information that the MRTDs seeks to collect on the ground of suppressing and preventing unlawful acts against civil aviation and as well eradicating documents' forgeries for the purpose of border crossing.

One fundamental principle of Islamic law is to "promote good and prevent evil" in the society. Therefore, the Islamic government must, in all ramifications, work toward this principle. It is not in contention that adoption of MRTDs in collection of personal information is against the principle of Islamic law on right to information privacy. However, where it is so clear that the public interests including but not limited to public security, safety and general rights of the community are in danger, then, Islam permits the government to set limitations to peoples' privacy. Thus, it is

71 Muhammad in History, Thought, and Culture. Editors: Coeli Fitzpatrick and Adam Honi Walter, ISBN 978-1610691772, p.59.

72 See Nasr, Seyyed Hossein, Dagli, Cancer K, Dakake, Maria Mossi, Lumbard, Josseph E.B, Tustom, Mohammod, The Study Quran: A New Translation and Commentary, Harper Collins (Kindle edition), p. 15198 (commentary to 5: 33.

73 See Nik Rahim Nik Wajis, The crime of Hirabah in Islamic Law, (unpublished Ph.D Thesis submitted to Glasgow Caledonian University, U.K, 1990) pp. 62-63. See also Mohammad Shabbir, Outlines of Criminal Law and Justice in Islam, (Malaysia: International Law Book Services, Selangor Darul Ehsan), p.176. 
necessary to know and have detail knowledge of would-be passenger before boarding the aircraft. This is done through the adoption of MRTDs in the interest of public safety and security. What is paramount is that such information must not be used for any purpose other than for what is collected. 